Polish crisis

\section{Patriotic science}

The role of science in overcoming Poland's economic difficulties will be a major point on the agenda of the next plenum of the Central Committee of the Polish United Workers' Party, Dr Hieronim Kubiak announced last week. Dr Kubiak, reputedly one of the most liberal members of the politburo, was addressing a national conference on "the role and tasks of science in getting the country out of the economic crisis"'.

Dr Kubiak stressed that "although science has no country, scientists do have countries', and appealed to the patriotic sentiments of all Polish scientists, asking them to rally to the new economic strategies.

From the Academy of Sciences, Dr Zdzislaw Kaczmarek, the scientific secretary, who holds quasi-ministerial rank and is accountable directly to the prime minister, announced a new government act, which will define the legal obligations implicit in scientific consultancy. Not every researcher, he said, has the qualities needed by a consultant, such as the ability to translate the language of science into the language of politics, and, most important of all, the courage to oppose "irrelevant" pressures.

The timing of the meeting was not without irony. On the same day, the Central Committee Commission for Health and Environment discussed a report on the disastrous level of environmental pollution - a subject which, until September 1980 could only be discussed in clandestine unofficial pamphlets. Even during the 16 months of Solidarity, the most revealing data, including the fluorine pollution of the Krakow area, could only be discussed in "internal" bulletins of the Polish Ecological Club. Yet now the commission cited "lack of adequate education" and information as a major cause of the current pollution levels. A few days before these meetings, another report had been under discussion in the Polish media - a discussion of the factors leading up to the imposition of martial law, produced by the "Experience and Future"' group (Doswiadczenie i Przyslosc, or DiP), an unofficial working party of intellectuals set up in 1978 to discuss the state of the country. In spite of official disapproval, DiP produced several reports on the economic crisis and proposed strategies for overcoming it. The latest such report, drawn up on 20 December, was ignored by the authorities until early March, when it was officially condemned as a Western forgery - although the same commentators then proceeded to vilify Stefan Bratkowski, head of DiP and chairman of the now-suspended Union of Polish Journalists. At least 30 scientists actively participated in DiP and have thus, effectively, had their proposals for the economy already rejected. How far they are liable to respond to Kubiak's patriotic appeals is unknown.

One notable figure, however, was absent from the meeting with Kubiak - Dr Aleksander Gieysztor, president of the Polish Academy of Sciences. He had been allowed to travel to Paris, to be honoured by a learned society for his contributions to historical research. The Paris ceremony was kept deliberately low-key, since Dr Gieysztor had made it clear that he was present solely in his private capacity, and not as a representative of the Polish scientific establishments. Vera Rich

\section{Universities in commerce \\ Stanford's way \\ Palo Alto}

Graduate students at Stanford University, denied entry to this week's conference on academic-industrial relations organized by the university's president, Dr Donald T. Kennedy, are holding a rival conference of their own in public. The Stanford graduate students' association has organized one meeting for 26 April and another for 10 May. The students' objectives are to help define their own reactions to the involvement of outside commercial interests in academic research and towards academic supervisors who acquire equity and managerial positions with companies whose interests are related to their research.

Kennedy has agreed to be the keynote speaker at the first of the students' meetings. Professor David Noble of the Massachusetts Institute of Science and Technology and author of American by Design, a study of the links between science and technology and the growth of corporations, will also be speaking.

For Kennedy's own meeting this week the presidents of Harvard University, the California Institute of Technology, MIT, the University of California and Stanford, together with teams of academic colleagues and industrial partners, are turning up at Pajaro Dunes. A possible code of practice to regulate the relationships between universities and commercial interests has been circulated, but even if this or some amended code is agreed on, the result will still have to be discussed within the faculties of the five universities.

One of Kennedy's messages for the students is likely to be that industrial corporations can contribute both financially and technically to the education of graduate students. He will be able to point to the arrangement now concluded between Stanford's new Center for Information Systems and seventeen major electronics companies, which will contribute $\$ 250,000$ a year for each of the next three years towards the general running costs.

Meanwhile, Stanford is taking steps to

\section{Joint Research Centre}

Jean-Albert Dinkespiler, an old hand at European research efforts, is to take over from Professor Stelio Villani as Director-General of the European Community's four "Joint Research Centres". The four centres at Ispra (Italy), Geel (Belgium), Karlsruhe (West Germany) and Petten (Netherlands) employ about 2,000 European scientists, and boast a budget for the period $1980-83$ of 510 million European Currency Units (£287 million).

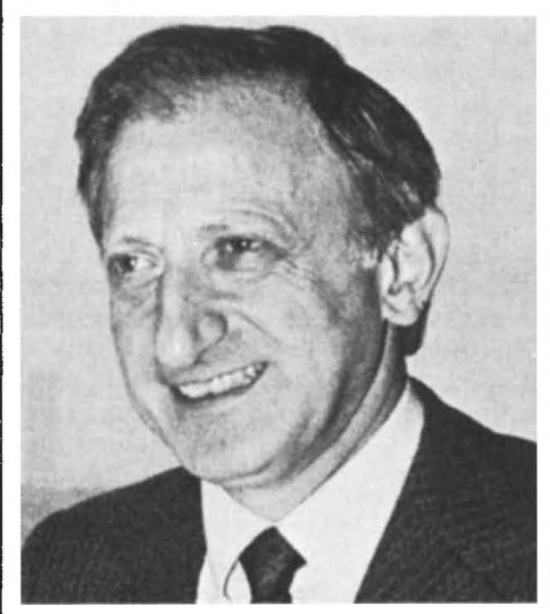

Dinkespiler, a 55-year-old Frenchman, has already seen active service at the French national centre for space studies, at the European Space Agency, as Deputy director-general of the Joint Research Centres and head of Ispra and most recently as director-general responsible for science, technology and energy at the Council of Ministers.

Jasper Becker

regularize the distribution and use of what is called "tangible research property" unpatentable products of research which may, nevertheless, have commercial value. New guidelines for the distribution and use by others than the original scientist have been drawn up partly to draw the attention of investigators to the possible commercial importance of such things as cell lines, computer data bases and software, circuit diagrams and engineering drawings.

Dr Gerald J. Lieberman, vice-provost at Stanford, says that investigators who create tangible research property should ordinarily be the ones who decide how it should be distributed or used. Such property should not be sold for profit, but steps should be taken to see that the assistance provided by academics at Stanford is afterwards recognizable (and, if necessary, acknowledged in writing). The objective seems to be to encourage researchers to assist their colleagues elsewhere while not hazarding the university's right to control the exploitation of those developments which turn out to have commercial value.

Charlotte Beyers 